\title{
Polyneuritis and herpes zoster
}

\author{
A. D. DAYAN, ${ }^{1}$ E. OGUL,${ }^{2}$ AND G. S. GRAVESON \\ From the Institute of Neurology, Queen Square, London, and Wessex Neurological Centre, Southampton
}

SUMMARY Widespread neurological disorders following herpes zoster are exceptional. They $\underset{0}{0}$ include encephalitis and myelitis, and a type of polyneuropathy. The latter is particularly rare as $\underline{\underline{O}}$ only 16 cases have been described since the first account by Wohlwill in 1924 . We present two clinical cases of polyneuropathy following herpes zoster with neuropathological studies on one of them, $\AA$ and discuss its possible aetiology and pathogenesis in the light of previous reports and recent experimental studies.

The case histories of our two patients are as follows.

\section{CASE 1}

This man, aged 66 years, was admitted to hospital in August 1969. Two weeks previously he had developed herpes zoster on the left side of the trunka typical erythematous and vesicular eruption, strictly limited by the midline, front, and back, in the D 7, 8, and 9 dermatome areas. One week before admission he began to notice weakness of his hands and legs with distal numbness of the extremities. This progressed so rapidly that in four days he was confined to bed.

Neurological examination two days after admission showed signs of a severe symmetrical polyneuritis. There was bilateral facial weakness but no other cranial nerves were involved. The arms were diffusely affected though no muscles were totally paralysed. The legs were paralysed except for slight movement of the quadriceps muscles. All tendon reflexes and the plantar responses were absent. Skin sensation was lost below the wrists and knees and joint sense was impaired in the toes. Calf tenderness was not increased.

One hour after this examination he was found dead in bed. The cerebrospinal fluid (CSF) had not been examined.

NECROPSY FINDINGS The heart (420 g) showed extensive patchy myocardial fibrosis and there was severe atheroma of the coronary arteries and aorta. The lungs were oedematous. The other viscera were congested. There was no evidence of generalized infection by herpes zoster, either on naked eye or microscopical examination. The cause of death was cardiac failure due to myocardial infarction.

${ }^{1}$ Requests for reprints to A. D. Dayan, Institute of Neurology, Queen Square, London WC1.

2 Permanent address: Çapa Neurological Clinic, University of Istanbul, Turkey.
CENTRAL NERVOUS SYSTEM The brain appeared normal externally and on slicing. In the spinal cord the 6th to 7th thoracic segments appeared oedematous. The left 7 th and 8 th thoracic posterior root $O$ ganglia were brown coloured and seemed friable.

An unsuccessful attempt was made to culture virus $\vec{\partial}$ from a necropsy sample of the right temporal lobe $\bigcirc$ in AM, HEL, and RK cells.

Serological studies were not done. HISTOLOGICAL EXAMINATION Cerebrum Basal ga glia, brain-stem, and cerebellum showed arterissclerotic changes only in small blood vessels. evidence was seen of encephalitis.

Spinal cord Scattered moderate cuffing by inflammatory cells of small vessels was seen in the root entry zone, posterior horn, and intermediolateral column regions on the left side only in the thoracic $\stackrel{\complement}{\Omega}$ region, most marked in the 7 th and 8th segments. $\overrightarrow{\vec{B}}$ Degeneration was seen of a single fasciculus of 3 myelinated fibres in the left posterior column in the $?$ 8th thoracic segment.

Spinal roots There was severe, active degeneration of axis cylinders and myelin sheaths in the 8th lefto thoracic posterior roots and scattered damaged 3 . fibres in the 7th left thoracic posterior roots at this? level. In paraffin sections posterior and anterior roots at all levels showed occasional degeneratingo myelin sheaths without any apparent damage to axis cylinders.

Posterior root ganglia Almost the entire lefto thoracic 8th ganglion was infarcted (Fig. 1) and N showed pale ghost outlines of neurones and satellite cells with extravasated erythrocytes and polymorphso in the stroma. There was a small zone of surviving cells near the anterior roots as they approached the ganglion to form the spinal nerve. Fibrinoid necrosis? was seen of small arteries and arterioles in and 
around the infarcted area (Fig. 2), but blood vessels in adjacent surviving tissues showed only variable degrees of cuffing by chronic inflammatory cells. In the left 6th and 7th thoracic ganglia small numbers of neurones appeared necrotic and there were a few nodules of inflammatory cells. Fibrinoid was found in the wall of a capsular arteriole in the left 6th thoracic ganglion. No inclusion bodies were seen.

Other posterior root ganglia at all levels and from both sides appeared normal. Samples of peripheral nerve trunks were not available for study. geminal nerve, 12 days before admission to hospital. Five days later tingling commenced in the hands and feet, and the following day his legs became so weak that he found walking difficult. The weakness got worse rapidly and two days before admission he had difficulty in swallowing.

Examination then revealed confluent, encrusted herpetic lesions over the right cheek, with some conjunctival injection. There was severe symmetrical weakness of all four limbs, worse distally. He was unable to stand or sit up. Tendon reflexes and plantar

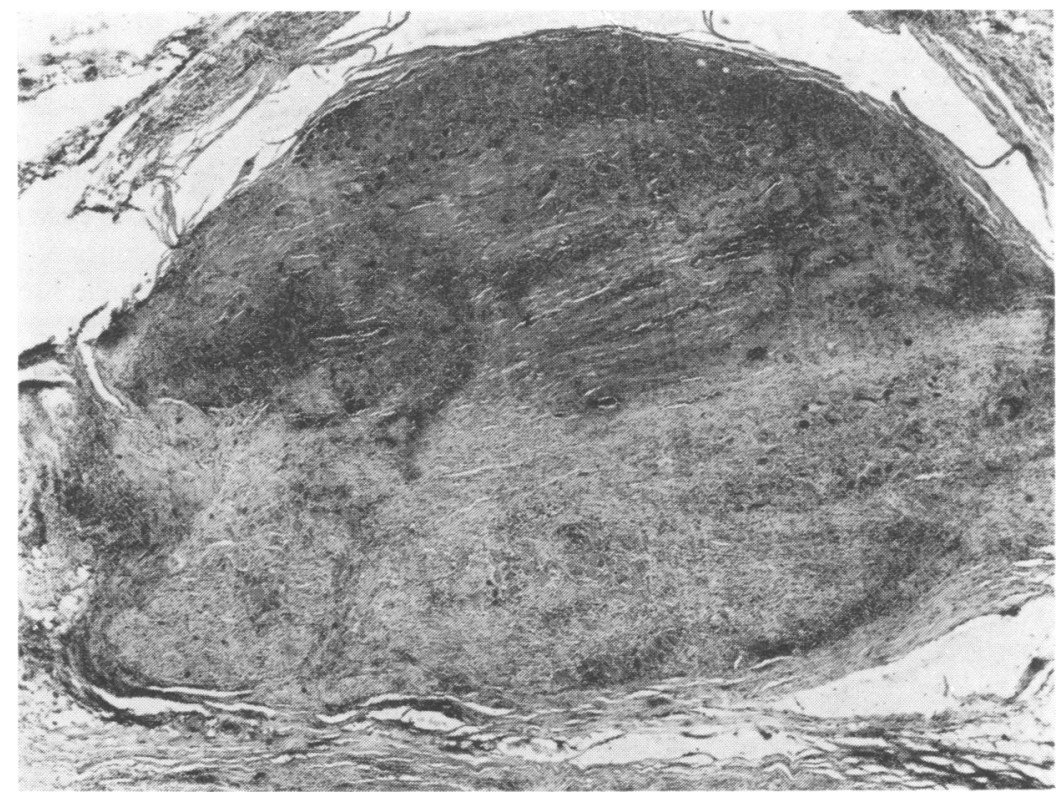

FIG. 1. Case 1. Partial infarction of left eighth thoracic posterior root ganglion. $H$ and $E, \times 22$.

Single nerve fibres were 'teased' from the left 7th cervical, 7th and 9th thoracic, and 2nd lumbar, and from the right 1st lumbar anterior and posterior nerve roots. They showed typical features of acute and healing segmental de- and re-myelination, including restricted paranodal damage (Fig. 3). No Wallerian-type destruction was seen affecting both axis cylinders and their Schwann cell-myelin sheaths.

\section{CASE 2}

A man, aged 53 years, developed a zoster eruption over the right cheek and inside the mouth in the distribution of the maxillary division of the tri- responses were absent. Skin sensation was impaired in the arms below mid-forearm level, and in the legs below mid-thigh; joint sense was lost in the toes, ankles, and knees but not in the fingers. Muscle tenderness was greatly increased. Cranial nerves were not affected except for weakness of the sternomastoid and pharyngeal muscles.

Examination of lumbar CSF showed no cells, and a protein content of $35 \mathrm{mg} / 100 \mathrm{ml}$.

Treatment with corticotrophin (ACTH) 60 units daily was started and a nasal gastric tube used for feeding.

No further extension of the polyneuritis occurred from the day of admission; improvement in power 
in both arms and legs was noted on the third day of treatment, and the gastric tube was no longer required thereafter. The upper limbs recovered faster than the legs. After 10 days the arms were normal except for minimal weakness of finger extension and hand muscles and by this time he could stand with some support. Sensation had improved in the arms but not in the legs. The dose of ACTH was reduced to 40 units alt. die. After a further week sensation

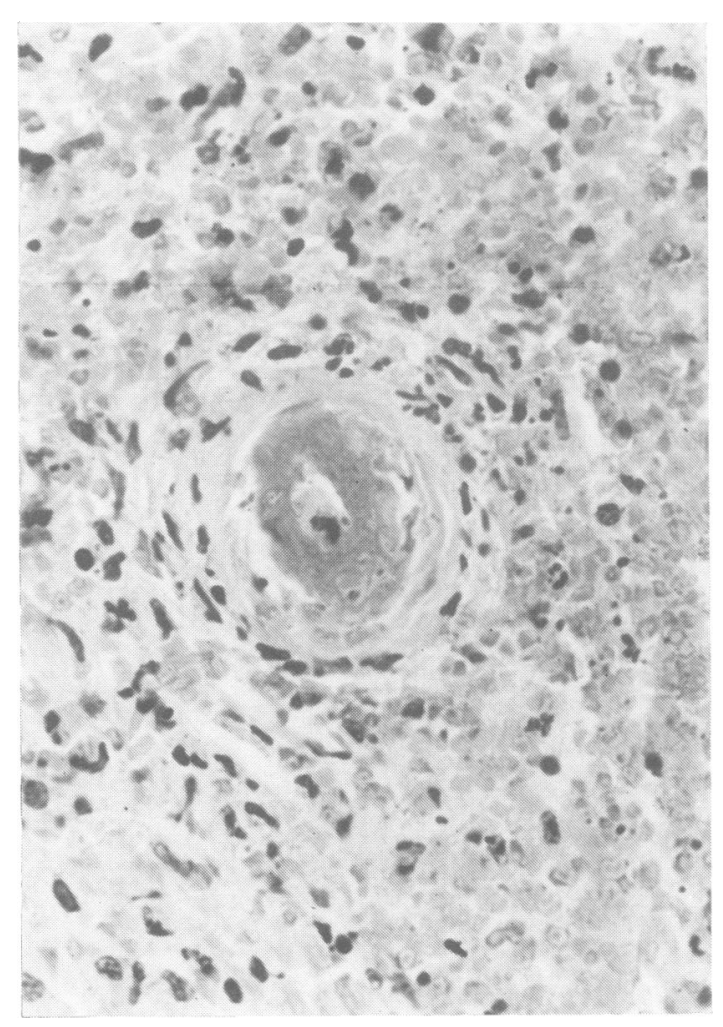

FIG. 2. Case 1. Fibrinoid necrosis of arteriolar wall in necrotic area of left eighth thoracic posterior root ganglion. A fibrin plug occludes the arteriole. $H$ and $E, \times 399$.

was normal in the legs and there was only minimal weakness in the anterior tibial group of muscles. ACTH was given then twice a week for one month. He returned home one month after admission. When last seen three months later he was well and all his tendon reflexes were brisk.

Investigations in the early phase of the illness included nerve conduction tests. On the ninth day of the polyneuritis they showed conduction at $25 \mathrm{~m} / \mathrm{sec}$ in the right lateral popliteal nerve, $31 \mathrm{~m} / \mathrm{sec}$ in the right median nerve, and $44 \mathrm{~m} / \mathrm{sec}$ in the right ulnar nerve. A sural nerve biopsy on the 12th day (teased preparation) showed some fibres with segmental demyelination and evidence of remyelination. A simultaneous biopsy of a quadriceps muscle showed occasional degenerated muscle fibres but no features of neurogenic atrophy. On the 12th day of the illness, the complement fixing antibody titre to varicella/zoster virus exceeded 1/320.

\section{DISCUSSION}

The history and clinical features of both our patients were typical of herpes zoster causing firstly a cutaneous eruption-'shingles' for example, in case 1 -and then a severe polyneuropathy. The morbid anatomical findings of infarction of one posterior root ganglion in case 1 , so severe as to merit the term 'spinal ganglion apoplexy' (Marburg, 1902), and the lesser degree of damage to a few nearby ganglia on the same side are identical with previous accounts of the histological lesions of this disease (Head and Campbell, 1900; Denny- o Brown, Adams, and Fitzgerald, 1944). Despite 을 the lack of serological confirmation, we con sider, therefore, that this patient's neurologicad $\frac{7}{0}$ illness was due to herpes zoster virus.

The polyneuropathy which case 1 developed $\overrightarrow{0}$ terminally was almost certainly due to genera ized demyelination of peripheral nerves, as suggested by the extensive and selective Schwann cell-myelin sheath lesions found in single nerve fibres isolated from the most proximal parts of spinal nerves and anterior and posterior nerve roots. In the absence of specimens of distal nerve trunks, a centripetal 'dying back' process involving combined axis cylinder and Schwann cell sheath degeneration (Cavanagh, 1964) cannot be excluded completely, but it seems very unlikely both on the clinical grounds of the natural history of such processes and pathologically, because of the severity of the proximal demyelination without any evidence of generalized axonal degeneration. Moreover, the periph- 9 eral nerve biopsy from case 2 , taken at a time of profound weakness, showed only Schwann cell damage and healing and intact axons.

Previous reports of the rare generalized polyneuropathy associated with herpes zoster are summarized in the Table. It has been associated with an initial zoster eruption in any part of the body, and has usually appeared acutely or $\stackrel{0}{ }$ subacutely, several days to a few weeks after the $\stackrel{\mathbb{Q}}{\rightarrow}$ eruption. As in the present cases, the neuropathy 
FIG. 3a. Case 1. Teased nerve fibres from left seventh cervical anterior spinal root showing acute paranodal de- and re-myelination. Osmic acid, $\times 165$.

FIG. 3b. Case 1. Consecutive lengths of a nerve fibre from right first and lumbar posterior spinal root showing pale short re-myelinated internodes after segmental demyelination. Osmic acid, $\times 165$.

has usually evolved with a symmetrical pattern and has affected the cranial nerves in eight of the 17 cases, particularly the facial nerves. Almost half of those affected have died, usually from acute respiratory failure due to involvement of trunk muscles and the diaphragm. Recovery has taken several months and has sometimes been incomplete. There appear to have been no previous necropsy studies of the pathology of this syndrome.

The pathogenesis of herpes zoster is still disputed but it is probably due to activation of a latent infection by external factors such as local trauma, age-associated waning of immunity, and others (Hope-Simpson, 1965). The virus then grows locally in susceptible cells and their processes, causing stereotyped cutaneous and neurological lesions, which are probably limited in duration and extent by a combination of immunological defences and stimulation of interferon production (Gold, 1966; Schubert, 1968; Armstrong, Gurwith, Waddell, and Merigan, 1970). A striking histological feature of posterior root ganglia affected by typical herpes zoster is the devastating, apparently ischaemic, infarction (Head and Campbell, 1900; Denny-Brown et al., 1944; Döring, 1955). Histologically, this lesion resembles those caused by an Arthus-type reaction in which circulating antibodies and complement damage tissue which contains a high local concentration of antigen (Coombs, 1968-type 1 reaction). This hypothesis is supported by the findings of fibrinoid necrosis of blood vessels in the most severely affected spinal ganglion in the present case, and by the pattern of infarction which suggests obstruction of the arterial supply to affected ganglia (Bergmann and Alexander, 1941). It is further supported by the lack of fibrinoid from the lesions of disseminated 
TABLE

\begin{tabular}{|c|c|c|c|c|c|c|c|c|}
\hline & \multirow[b]{2}{*}{$\begin{array}{l}\text { Sex, } \\
\text { age }(y r)\end{array}$} & \multirow{2}{*}{$\begin{array}{l}\text { Interial } \\
\text { zoster- } \\
\text { poly- } \\
\text { neuritis }\end{array}$} & \multirow{2}{*}{$\begin{array}{c}\text { Sen- } \\
\text { sory } \\
\text { dis- } \\
\text { turb- } \\
\text { ance }\end{array}$} & \multirow{2}{*}{$\begin{array}{l}\text { Cranial } \\
\text { nerve } \\
\text { involve- } \\
\text { ment }\end{array}$} & \multirow[b]{2}{*}{ Onset } & \multicolumn{2}{|c|}{ Lumbar CSF } & \multirow[b]{2}{*}{ Course } \\
\hline & & & & & & $\begin{array}{c}\text { Cells } \\
(c . m m)\end{array}$ & $\begin{array}{c}\text { Protein } \\
(\mathrm{mg} / 100 \mathrm{ml} .)\end{array}$ & \\
\hline 1. Wohlwill (1924) & F 44 & 2 weeks & + & - & Acute & Normal & Raised & $\begin{array}{l}\text { Quadriparesis. } \\
\text { Death in } 2 \text { days }\end{array}$ \\
\hline 2. Schubach (1930) & F 62 & 7 days & $?$ & - & Acute & $?$ & $?$ & $\begin{array}{l}\text { Quadriparesis. } \\
\text { Death in } 5 \text { days }\end{array}$ \\
\hline 3. Riser and Sol (1933) & M 30 & 2 months & + & - & Insidious & Normal & 1,750 & $\begin{array}{l}\text { Quadriparesis. } \\
\text { Recovery, residual } \\
\text { areflexia }\end{array}$ \\
\hline $\begin{array}{l}\text { 4. Gilpin, Moersch, and } \\
\text { Kernohan (1936) }\end{array}$ & M 52 & Few days & $\begin{array}{l}+ \\
+\end{array}$ & $\begin{array}{l}\text { Bilateral } \\
\text { VII }\end{array}$ & Subacute & Normal & Raised & $\begin{array}{l}\text { Quadriparesis. } \\
\text { Death in } 2 \text { months }\end{array}$ \\
\hline $\begin{array}{l}\text { 5. Maggi, Meeroff, Cosen, } \\
\text { and Hirschman (1956) }\end{array}$ & M 68 & 1 month & + & Right VIII & Insidious & Normal & Normal & $\begin{array}{l}\text { Quadriparesis. } \\
\text { Partial recovery in } \\
4 \text { months }\end{array}$ \\
\hline 6. Friart and Jeanty (1956) & F 72 & $?$ & + & - & Subacute & 25 & 3,300 & $\begin{array}{l}\text { Paraparesis. } \\
\text { Recovery in } 5 \text { months }\end{array}$ \\
\hline 7. Stammler and Struck (1958) & F 66 & 3 days & + & Bulbar & Acute & 430 & 5,000 & $\begin{array}{l}\text { Quadriparesis. } \\
\text { Death }\end{array}$ \\
\hline 8. Pálffy and Balázs (1959) & F 63 & 2 months & + & 一 & Insidious & 9 & 146 & $\begin{array}{l}\text { Quadriparesis. } \\
\text { Recovery in } 6 \text { months }\end{array}$ \\
\hline 9. Pảlffy and Balázs (1959) & F 53 & 7 days & + & Bulbar & Acute & 14 & 24 & $\begin{array}{l}\text { Quadriparesis. } \\
\text { Death in } 12 \text { days }\end{array}$ \\
\hline $\begin{array}{l}\text { 10. Duperrat and Pringuet } \\
\text { (1958) }\end{array}$ & M 53 & 2 days & 0 & Right VII & Acute & 3 & 480 & $\begin{array}{l}\text { Quadriparesis. } \\
\text { Death in } 10 \text { days }\end{array}$ \\
\hline $\begin{array}{l}\text { 11. Knox, Levy, and Simpson } \\
(1961)\end{array}$ & M 69 & 2 weeks & + & - & Insidious & 3 & 50 & $\begin{array}{l}\text { Quadriparesis. } \\
\text { Death in } 5 \text { months }\end{array}$ \\
\hline $\begin{array}{l}\text { 12. Knox, Levy, and Simpson } \\
(1961)\end{array}$ & M 54 & 7 weeks & + & 一 & Acute & 8 & $89-150$ & $\begin{array}{l}\text { Quadriparesis. } \\
\text { Recovery in } 4 \text { months }\end{array}$ \\
\hline $\begin{array}{l}\text { 13. Knox, Levy, and Simpson } \\
(1961)\end{array}$ & F 65 & 7 weeks & + & Right III & Subacute & 4 & 162 & $\begin{array}{l}\text { Quadriparesis. } \\
\text { Partial recovery in } \\
3 \text { months }\end{array}$ \\
\hline 14. Levanti and Védy (1963) & M 35 & $?$ & $?$ & $\begin{array}{l}\text { Bilateral V, } \\
\text { L. VI, } \\
\text { R. VII }\end{array}$ & Subacute & 19 & 403 & Paraparesis. Recovery \\
\hline $\begin{array}{l}\text { 15. Bonduelle, Bouygues, and } \\
\text { Chemaly (1963) }\end{array}$ & F 63 & 2 months & + & - & Insidious & Normal & 300 & $\begin{array}{l}\text { Quadriparesis. } \\
\text { Recovery in } 3 \text { months }\end{array}$ \\
\hline $\begin{array}{l}\text { 16. Nevsimal and Lehovsky } \\
\text { (1963) }\end{array}$ & M 67 & $?$ & 0 & $\begin{array}{l}\text { Bulbar } \\
\text { bilateral } \\
\text { VII }\end{array}$ & - & 3 & 122 & Quadriparesis. Recovery \\
\hline $\begin{array}{l}\text { 17. Castellotti and Pittalugo } \\
(1965)\end{array}$ & F 64 & $?$ & 0 & - & $?$ & Normal & 1,100 & Quadriparesis. Recovery \\
\hline $\begin{array}{l}\text { 18. Dayan, Ogul and Graveson } \\
\text { (1971) }\end{array}$ & M 67 & 1 week & + & Bilateral VII & Acute & - & 一 & $\begin{array}{l}\text { Quadriparesis. } \\
\text { Death in } 2 \text { weeks }\end{array}$ \\
\hline $\begin{array}{l}\text { 19. Dayan, Ogul and Graveson } \\
\text { (1971) }\end{array}$ & M 53 & 5 days & + & R. V & Subacute & 0 & 35 & $\begin{array}{l}\text { Quadriparesis. } \\
\text { Recovery in } 1 \text { month }\end{array}$ \\
\hline
\end{tabular}

herpes zoster found in patients with impaired immunity (Dayan, Morgan, Hope-Stone, and Boucher, 1964).

Herpes zoster polyneuropathy develops after a variable latent period and, in the present cases at least, is due to demyelination of the peripheral nerves, a mechanism sometimes proposed in the more typical radiculopathy (Norris, Dramov, and Johnson, 1968). Both these observations strongly suggest that it is due to 'allergic' damage directed against an antigen in Schwann cells or peripheral nerve myelin, a mechanism similar to that proposed for other forms of demyelinating peripheral neuropathies-for example, acute post-infectious polyneuritis (Melnick, 1964; Knowles, Saunders, Currie, Walton, and Field, 1969; Currie and Knowles, 1971). The apparent- ly dramatic response of case 2 to ACTH also lends support to this hypothesis. In fact no previously reported case seems to have recovered so quickly. Knox, Levy, and Simpson (1961) were the first to suggest an allergic disturbance 8 as the cause of herpetic polyneuritis. Their three cases developed polyneuritis at rather, long 음 intervals after shingles (four, six, and seven $D$ weeks) and showed no definite response to prednisolone. They felt that steroid therapy $N$ should be started as early as possible if it is to be effective, and our case 2 exemplifies the point.

Previous surveys of viruses in the aetiology of $\mathrm{C}$ the 'Guillain-Barré syndrome' have not considered the herpes zoster-varicella virus (Mel- $\stackrel{\circ}{C}$ nick and Flewett, 1964; summarized by Asbury, Arnason, and Adams, 1969), but it, too, should 
be taken intoraccount in view of the ubiquitous nature of human infection by it. The very uncommon clinical occurrence of zoster polyneuropathy may be due to the body's ability either to prevent such an 'autoimmune' reaction from occurring at all, or to minimize its effects so that they remain at a subclinical level. If so, it would be worthwhile examining typical cases of herpes zoster for electrophysiological evidence of a subclinical demyelinating neuropathy, as well as employing immunological tests (and histological techniques, should suitable tissue become available), in order to discover what rare combination of factors precipitates the very unusual clinically apparent manifestation of herpes zoster polyneuropathy.

We thank Dr. W. O'Driscoll of Portsmouth and Dr. G. J. Thorpe of Ryde who referred these patients to us. We are grateful to Dr. R. D. Clay for his help with the necropsy of case 1 , to Dr. R. A. Goodbody for the nerve biopsy of case 2, to Mr. J. A. Mills and Miss M. I. Stokes for their skilled assistance, and for support by the Cancer Research Campaign. Dr. Ogul is a British Council Scholar.

\section{REFERENCES}

Armstrong, R. W., Gurwith, M. J., Waddell, D., and Merigan, T. C. (1970). Cutaneous interferon production in patients with Hodgkin's disease and other cancers infected with varicella or vaccinia. New England Journal of Medicine, 283, 1182-1187.

Asbury, A. K., Arnason, B. G., and Adams, R. D. (1969). The inflammatory lesion in idiopathic polyneuritis. Its role in pathogenesis. Medicine, 48, 173-215.

Bergmann, L., and Alexander, L. (1941). Vascular supply of the spinal ganglia. Archives of Neurology, 46, 761-782.

Bonduelle, M., Bouygues, P., and Chemaly, R. (1963). Les polyradiculonévrites post-zostériennes. Revue Neurologique, 108, 5-12.

Castellotti, V., and Pittaluga, E. (1965). Sindrome di GuillainBarré postzosteriana. Rivista di Patalogia Nervosa $e$ Mentale, 86, 417-429.

Cavanagh, J. B. (1964). The significance of the 'dying back' process in experimental and human neurological disease. International Review of Experimental Pathology, 3, 219-267.

Coombs, R. R. A. (1968). Immunopathology. British Medical Journal, 1, 597-602.

Currie, S., and Knowles, M. (1971). Lymphocyte transformation in the Guillain-Barré syndrome. Brain, 94, 109-116.

Dayan, A. D., Morgan, H. G., and Hope-Stone, H. F., and Boucher, B. J. (1964). Disseminated herpes zoster in the reticuloses. American Journal of Roentgenology, Radium Therapy, and Nuclear Medicine, 92, 116-123.

Denny-Brown, D., Adams, R. D., and Fitzgerald, P. J. (1944). Pathologic features of herpes zoster. A note on 'geniculate herpes'. Archives of Neurology, 51, 216-231.

Döring, G. (1955). Pathologische Anatomie der Spinal- und Hirnnervenganglien. In Handbuch der speziellen pathologischen Anatomie und Histologie, 13 Bd. 5 Teil, pp. 249-
356. Edited by O. Lubarsch, F. Henke and R. Rössle. Springer: Berlin.

Duperrat, B., and Pringuet, R. (1958). Zona thoracique suivi d'une quadriplégie ascendante d'évolution mortelle. Discussion nosologique. Bulletin de la Société Française de Dermatologie et de Syphilographie, 65, 257-258.

Friart, J. and Jeanty, C. (1956). Zona associé à un syndrome de Guillain-Barré avec hypotension orthostatique. Revue des complications motrices du zona. Acta Clinica Belgica, 11, 365-382.

Gilpin, S. F., Moersch, F. P., and Kernohan, J. W. (1936). Polyneuritis. A clinical and pathologic study of a special group of cases frequently referred to as instances of neuronitis. Archives of Neurology and Psychiatry, 35, 937-963.

Gold, E. (1966). Serologic and virus-isolation studies of patients with varicella or herpes-zoster infection. New England Journal of Medicine, 274, 181-185.

Head, H., and Campbell, A. W. (1900). The pathology of herpes zoster and its bearing on sensory localisation. Brain, 23, 353-523.

Hope-Simpson, R. E. (1965). The nature of herpes zoster: a long-term study and a new hypothesis. Proceedings of the Royal Society of Medicine, 58, 9-20.

Knowles, M., Saunders, M., Currie, S., Walton, J. N., and Field, E. J. (1969). Lymphocyte transformation in Guillain-Barré syndrome. Lancet, 2, 1168-1170.

Knox, J. D. E., Levy, R., and Simpson, J. A. (1961). Herpes zoster and the Landry-Guillain-Barré syndrome. Journal of Neurology, Neurosurgery, and Psychiatry, 24, 167-172.

Levanti, J., and Védy, J. (1963). Manifestations polyradiculonévritiques ascendantes et zona intercostal. Médicine Tropicale, 23, 691-694.

Maggi, A. L. C., Meeroff, M., Cosen, J. N., and Hirschman, B. (1956). Trastornos motores en el herpe zoster: un caso con cuadriplejia. Prensa Médica Argentina, 43, 1970-1974.

Marburg, O. (1902). Zur Pathologie der Spinalganglien. Arbeiten aus dem Neurologischen Institut an der Wiener Universität, 8, 103-189.

Melnick, S. C. (1963). Thirty-eight cases of Guillain-Barré syndrome: an immunological study. British Medical Journal, 1, 368-373.

Melnick, S. C., and Flewett, T. H. (1964). Role of infection in the Guillain-Barré syndrome. Journal of Neurology, Neurosurgery, and Psychiatry, 27, 396-407.

Nevsímal, O., and Lehovský, M. (1963). Zosterová polyradikuloneuritida probíhající pod obrazem Landryho paralýzy. Ceskoslovenská Neurologie, 26, 280-283.

Norris, F. H. jr., Dramov, B., and Johnson, S. G. (1968). Neuromyositis in a patient with recurring herpes zoster. Transactions of the American Neurological Association, 93, 253-256.

Pálffy, G., and Balázs, A. (1959). Myeloradiculoganglionitis following zoster. Archives of Neurology and Psychiatry, 81, 433-438.

Riser, M., and Sol, A. (1933). De la névraxite zostérienne. Lésions du système nerveux central dans le zona. Encéphale, 28, 380-392.

Schuback, A. (1930). Herpes zoster und Landrysche Paralyse. Zeitschrift für die gesamte Neurologie und Psychiatrie, 123, 424-433.

Schubert, H. (1968). Immunologische Gesichtspunke zur Pathogenese des Zoster. Zeitschrift für ärztliche Fortbildung, 62, 528-532.

Stammler, A., and Struck, G. (1958). Zur Klinik und Pathomorphologie der polyradiculomyelitischen Verlaufsform des Zoster. Deutsche Zeitschrift für Nervenheilkunde, 178, 313-329.

Wohlwill, F. (1924). Zur pathologischen Anatomie des Nervensystems beim Herpes Zoster. Zeitschrift fïr die Neurologie und Psychiatrie, 89, 171-212. 